\title{
DESIGN AND DEVELOPMENT OF SEMI-AUTOMATED CLIP BRACKET IN
}

\section{AUTOMOTIVE}

\section{P. VIGNESH ${ }^{1}$, D. MOHANKUMAR ${ }^{2}$, M. PARIVALLAL ${ }^{3}$ \& JAGADEESH VIKRAM. C $^{4}$ \\ ${ }^{1,3}$ Assistant Professor, Department of Mechanical Engineering, Indira Institute of Engineering and Technology,} Pandur, Thiruvallur, Tamil Nadu, India

${ }^{2}$ Assistant Professor, Department of Automobile Engineering, Bharath Institute of Higher Education and Research, Tamil Nadu, India

${ }^{4}$ Associate Professor, Department of Automobile Engineering, Bharath Institute of Higher Education and Research,

Tamil Nadu, India

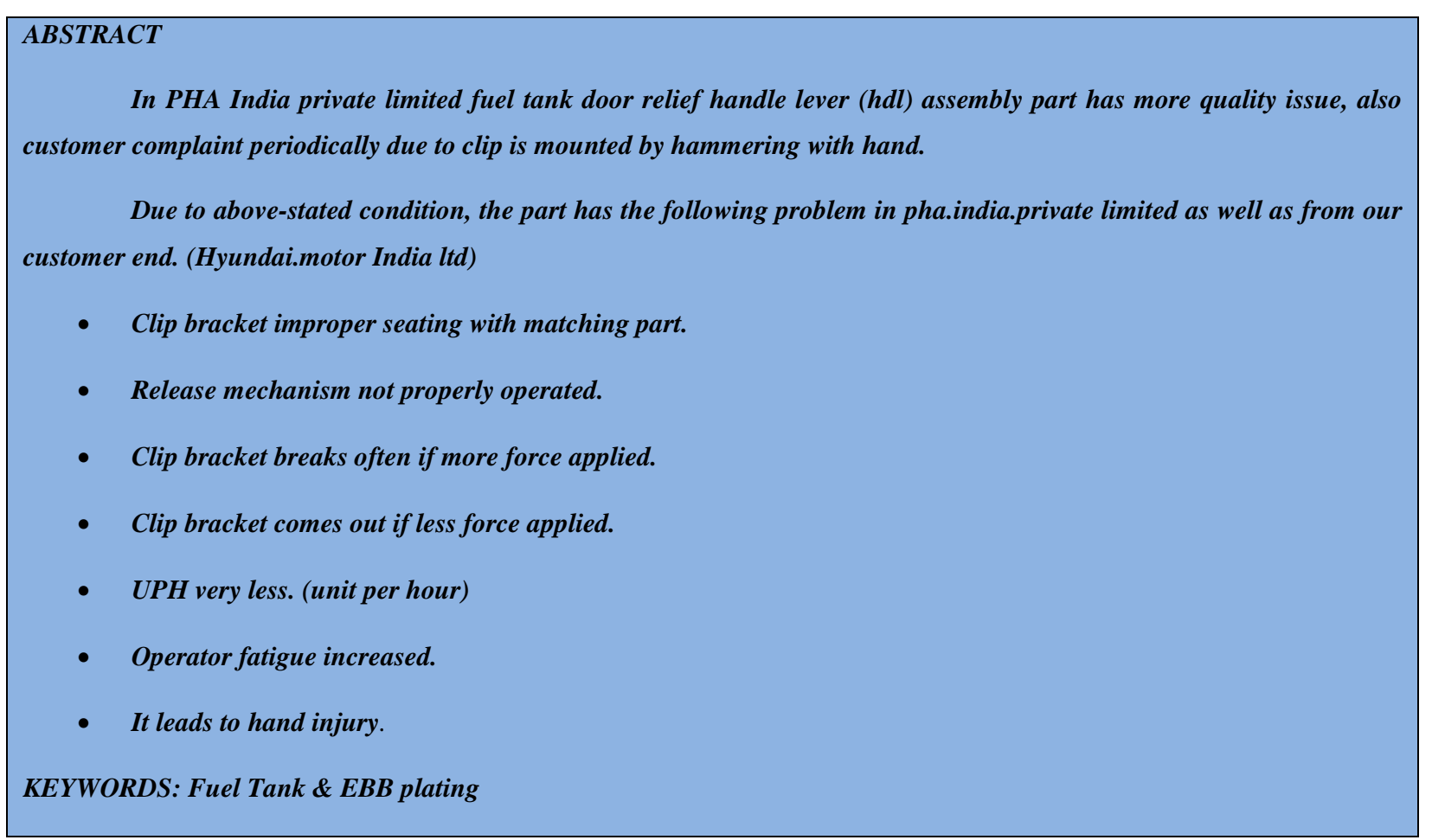

Received: May 21, 2019; Accepted: Jun 11, 2019; Published: Sep 07, 2019; Paper Id.: IJMPERDAUG2019145

\section{INTRODUCTION}

\section{To Research Work}

In our company fuel filler bracket assy is assembled with 3 main components which include 2 metal components stamped from 200TON NC stamping press and a plastic component that comes from 110TON injection moulding [1-6]. After stamping it goes to plating namely EBB plating and the mould parts go to laser printing for customer identification after injection moulding [7-11]. The 3 parts assembled by the manual method in PHA assy shop and are moved to our customer end. 


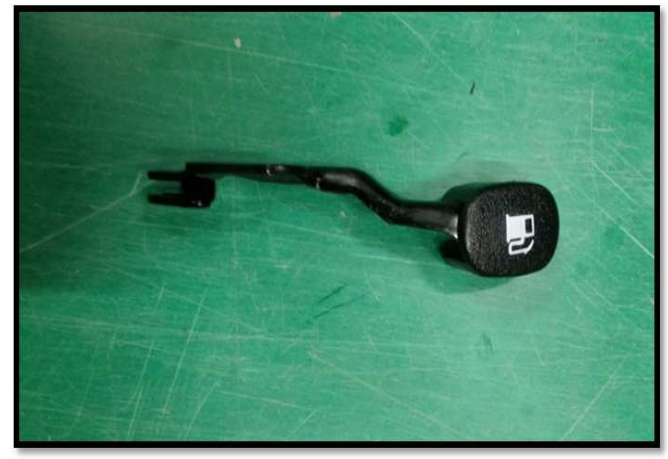

Figure 1: Fuel Filler Bracket Assembly

\section{NEED OF THE RESEARCH WORK}

The main aim of the research work is to analyse and improve the quality by changing the semi-automation line. The first reason why we chose this research work is that we were unable to meet our customer demand. So we decided on the process to improve capacity in the assembly line.

Frequently the answer is found with new technology solutions. Solution for the problem is to make feasible changes in the existing flushing process which is best performed already [12-15]. The daily demand from the customer is very difficult to meet with the existing flushing process. To satisfy customer, we are in the position of manufacturing parts at low cost and high productivity with better quality. Hence it becomes essential to reduce the cost and improve productivity to meet the customer demand [16-21]

\section{FUNCTION OF THE PRODUCT}

The main function of the fuel filler bracket is used to lifting the fuel tank cover in driver seat itself in cars such as Santro, Accent, i10, and i20.

It is fixed with nearby clutch and brake pedal and it is operated by driver's hand and for easy identification, the logo is printed on top of the lever[22-28].

When the lever is pulled up the fuel cover is opened through a linked mechanism. After filling the fuel the cover is closed manually.

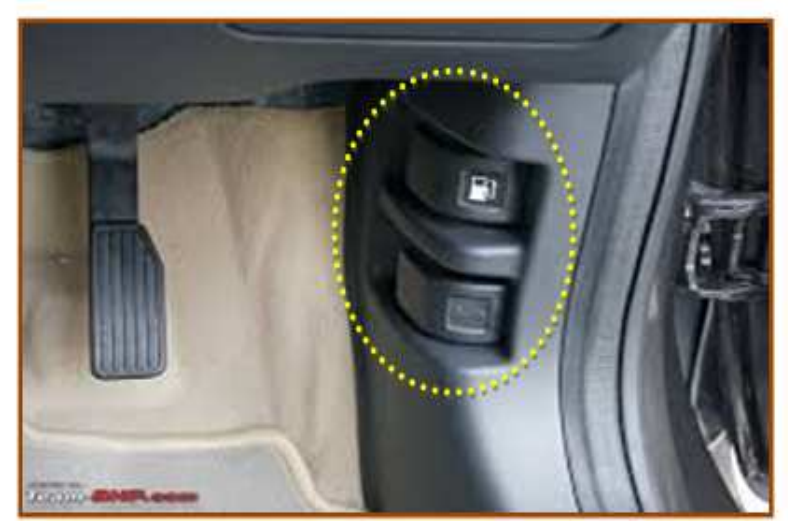

Figure 2: Fuel Filler Handle Lever present Location in Car 


\section{PROBLEM DEFINITION}

In our company's assembly line, the fuel filler bracket assembly is done by using the hammer. While in hammering the component sometimes damages as hammering depends on operator power and when this action is done repeatedly the force is fluctuated [29-31].

Due to this condition, the knob (moulding part) is possible to be broken.

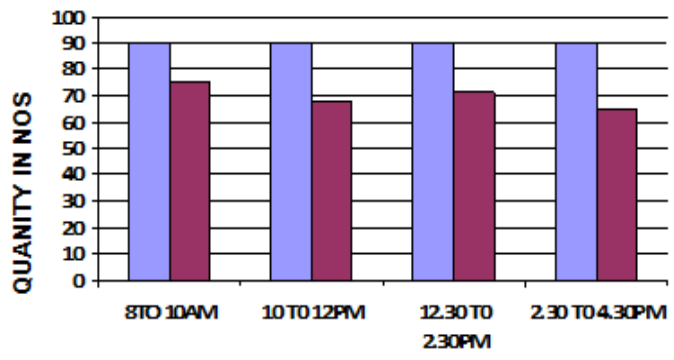

TIME IN HOURS

Figure 3: UPH Plan vs Actual

Our assembly line production unit per hours target is 90 nos. but in the present condition, we cannot meet our target as the operator's manual skills are considered to meet our target

\section{INTRODUCTION THE PROCESS FLOW}

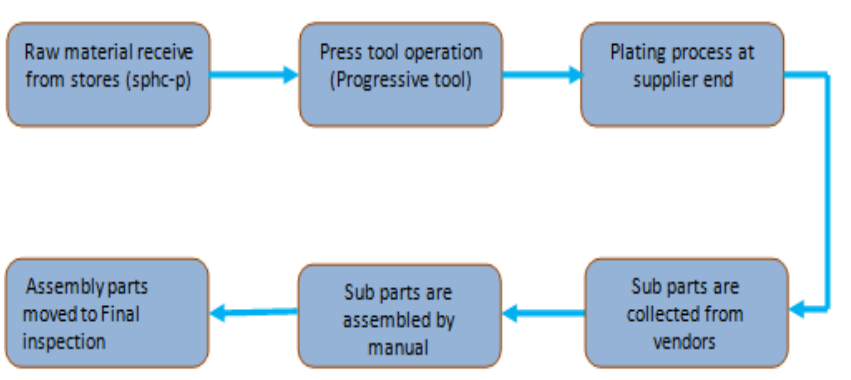

Figure 4: Process Flow of Fuel Handle Relief Lever Assembly

\section{REJECTION ANALYSIS}

In our company, the fuel filler bracket rejection is comparatively high due to various reasons. The torque uneven is a major problem that we are facing. The last year's rejection trend is shown below.

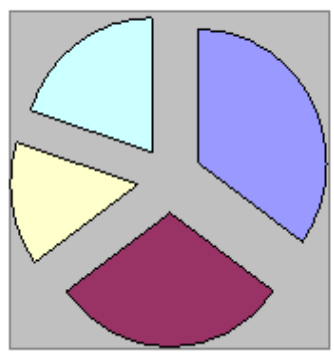

\begin{tabular}{|l|}
\hline TORQUE MORE \\
$\square$ TORQUE LESS \\
$\square$ KNOB BROKEN \\
$\square$ BAD APP ERANCE \\
\hline
\end{tabular}

Figure 4: Rejection Analyses 


\section{IDEAS FOR PROCESS IMPROVEMENT}

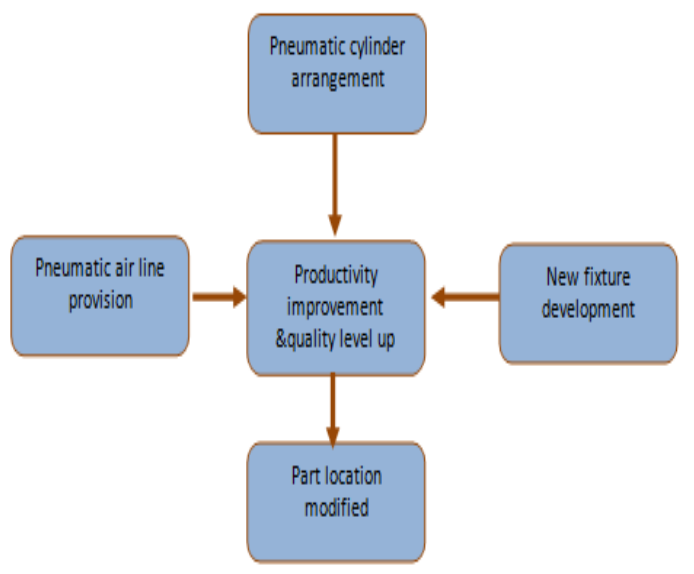

Figure 5: Analysis Chart to Improve the Process

From the above chart, we can make changes in the following data to improve and sustain the process.

\section{PNEUMATIC CYLINDER ARRANGEMENT}

Acceptable to change the design

\section{PNEUMATIC AIRLINE PROVISION}

Flushing is essential for the injector to maintain the cleanliness level.

\section{NEW FIXTURE DEVELOPMENT}

The flushing time reduced to be affected next stage process due to the failure of the next stage cleanliness. The Test plans run as per customer requirement.

\section{PART LOCATION MODIFIED}

Not possible to combine the process next machine. Another machine function not related to the flushing process.

\section{AUTOMATION}

Automation includes the use of various control systems to operate equipment such as machinery, plant processes, boilers and heat treatment furnaces, to modify telephone networks, to route and to balance ships.. Aircraft and other applications with minimal or reduced human intervention. Some operations are fully automated.

\section{ASSEMBLY FIXTURE SELECTION}

- $\quad$ Fixture design for ASSEMBLY process steps,

- 3D modelling with the help of NX-9 software.

- 2D Drawing with the help of Auto CAD software.

- Material selection.

- Design parameter \& Calculation.

- Inspection.

- Result. 


\section{FIXTURE}

The luminaire is a fixture used in the manufacturing industry. It is used to attach accessories (placement in a specific location or orientation) and to support the work [32-36]. Improving the efficiency of production by simplifying installation, reducing the need for skilled labour and increasing the compatibility of workers in production.

A device differs from the device in that the tool must move relative to the work piece when using a device; When the tool stops, a device moves apart. The luminaire must always be designed taking into account the economic efficiency; Since the purpose of these devices is to reduce costs, the cost reduction must be designed to overcome the cost of using the light. From an economic point of view, it is preferable to translate armour into a low-cost reduction for a continuous operation process, rather than a significant cost reduction for an occasional process.

Most accessories have a fixed component which is fixed to the floor or body of the machine, which is stationary with respect to the movement of the machining tool and has one or more movable components called clamps. These clamps (which can be used in various mechanical ways) ensure that the parts can be easily inserted into or removed from the machine and that they remain safe during operation. Many are also adjustable and allow the use of parts of different sizes for different operations. Luminaires should be designed so that the pressure or movement of the machining process (generally referred to as the power supply) is primarily directed to the fixed part of the luminaire. This reduces the risk of equipment failure, downtime and possible damage to infrastructure, components or operators.

\section{FACTOR FOR FIXTURE SELECTION}

Fixtures for flushing are designed in PRO-E \& Auto cad software. Variety of fixture model created can be used for the flushing process. Finally, the capable fixture is designed. The flushing fixture clamping and decamping by using 23 pneumatic control. Because Pneumatic system is better than a hydraulic system. Also low-cost automation process.

Locating Bunk designed through-hole with 'O' ring to avoid Oil Leakage. The butting injector designed inclined for easy loading purpose. Based on the existing Fixture design the HP pipeline fixed one by one per components. Now HP pipeline fixed through a manifold. The drawing of the existing is proposed.

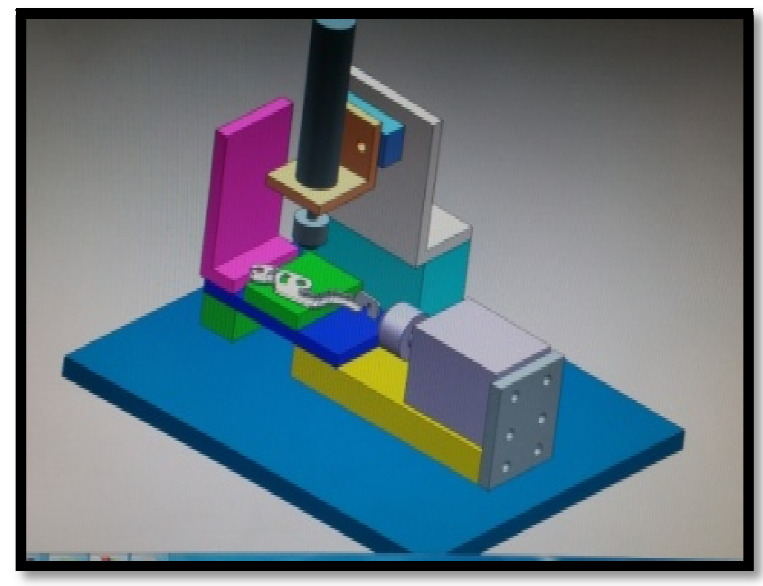

Figure 6: Fixture 3D View 


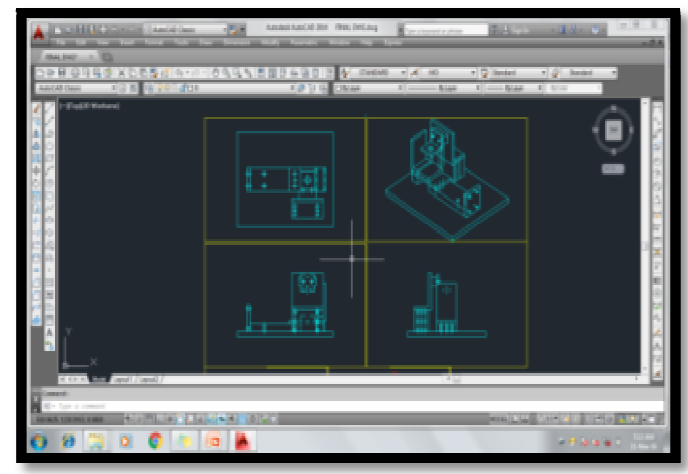

Figure 7: New Fixture 2d Assembly View

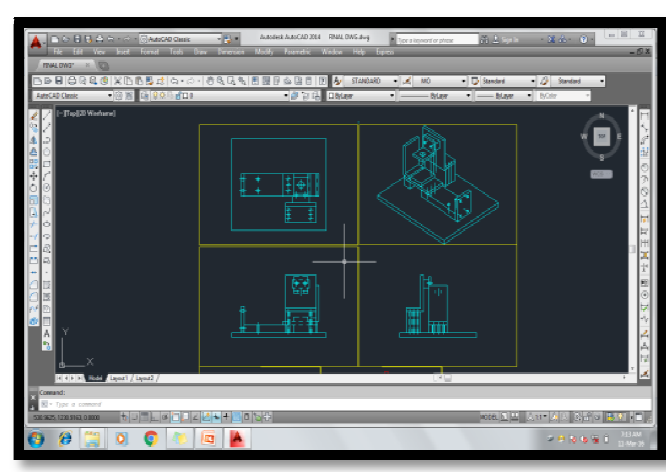

Figure 8: New Fixture 2D Front View

\section{SELECTION OF CLAMPING CYLINDER}

While selecting of clamping cylinder, first clamping mechanism types are pneumatic and hydraulic methods. The pneumatic system is good for this application. So we chose Pneumatic cylinder selection to be taken with calculation.

The diameter of the cylinder selection process:

Applying load in $\mathrm{kg}$

\section{Working Force Calculation}

Force $=$ Pressure $\times$ Area [Line pressure $5 \mathrm{bar}=5 \mathrm{~N} / \mathrm{mm} 2]$

$=5 \times \mathrm{d} 2 .[$ Dia of the component $=18 \mathrm{~mm}]$

$=5 \times \pi / 48^{*} 12^{2}$

$=1271.7 \mathrm{~N}$

\section{Cylinder Diameter Calculation}

\section{FORCE}

Pressure $=$ AREA

Area $=\pi / 4 * D^{2}$

$\underline{1271.5}$

$5=\pi / 4 * \mathrm{D}^{2}$

$\mathrm{D} 2=323.23 \mathrm{~mm} 2$

$\mathrm{D}=17.99 \mathrm{~mm}$

\section{FACTOR OF SAFETY}

From the design data book the Factor of safety for cylinder diameter 10 to $20=3$ to

4times. Hence the cylinder's diameter is $18 \mathrm{~mm}$ for which Factor of safety is 3.2 times

Diameter of the cylinder $=18 \times 3.2$ 
Diameter of the cylinder $=57.6 \mathrm{~mm}$

We consider the calculation and selecting the Pneumatic Cylinders in the diameter of $63 \mathrm{~mm}$.

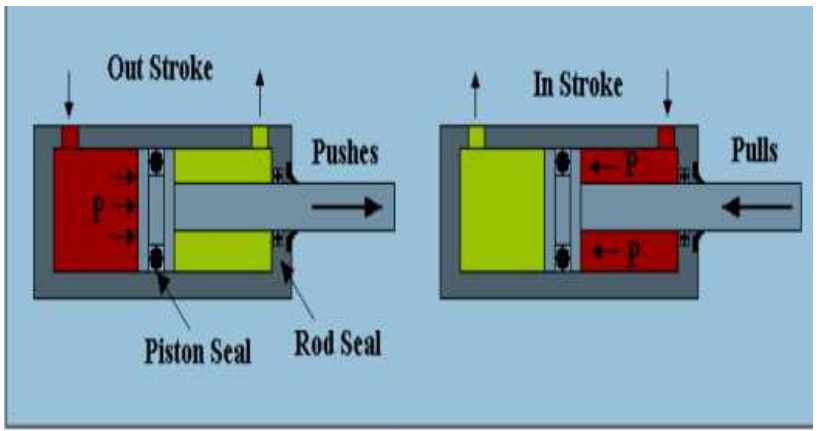

Figure 9: Cylinder Push and Pull Vie

\section{PROCESS QUALIFICATION}

The manufacturing system needs to be operated by the machine just like it is intended to run in production mode without affecting the process parameters. Exercises the equipment/manufacturing system again to find infant mortality uptime issues.

The following are things are considered while there is a change or modification process.

- Machine cycle time study,

- Process capability study,

- First-time quality trend,

- $\quad$ Process parameters updating.

For any process it is necessary to run production, minimum of 30nos continuous sample or $8 \mathrm{hrs}$ production for, to qualify for the procession. In our case, we take continuous 30nos sampling plan to qualify the process in the aboveMentioned considerations

\section{MACHINE CYCLE TIME STUDY}

The time required for a particular task to be repeated once is usually measured from "start," the start point of the process, from one product in the specified machine or process to the start of processing of another product. Similar to the same machine or the same process. The cycle time is generally classified info:

\section{Manual Cycle Time}

Load and unload parts while the part is in the same system/process. Add parts to the rotor.

\section{Machine Cycle Time}

The processing time of the whole machine.

\section{Auto Cycle Time}

The time a machine runs automatically without manual activity.

\section{Overall Cycle Time}

The time required for the production unit. This term is often used to refer to a single system or process. 


\section{Total Cycle Time}

This includes all categories of machinery, processes and deadlines that must go through the product until it is the final product. This is not a delivery date, but it will help you make a decision. In most cases, the type of session duration is not important. The total duration of the session must be less than the connection time.

\section{PROCESS CAPABILITY STUDY}

The process capability of a process is the extent of variation in the Quality characteristic of the process output when the process is operating in a state of Statistical control under a given set of conditions.

It concerns with the ability of the process to produce output meeting specifications consistently. Takes into account variation caused by all the possible sources of variation.

\section{Uses of Process capability study}

- $\quad$ Provide Information to facilitate the design of product characteristics/tolerance.

- Assist process planners to select or modify a process

- Assist in establishing the interval between sampling for Process Control

- $\quad$ Specify the performance requirement of a new process

- Compare the capability of various processes

- Assigning work to machines

- $\quad$ Selecting between competing vendors

- Determining the economic nominal for an operation

- $\quad$ Reducing the variability in a process.

\section{TORQUE QUALITY TREND}

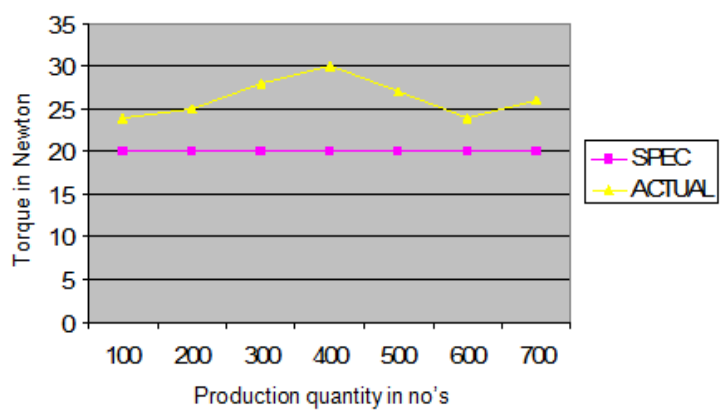

Figure 10: Torque Analysis

Torque is a very important factor so that the lever could not come out while operating the lever. After implementing the semi-automation with the help of pneumatic cylinder, torque was achieved and the problem was eliminated.

\section{SUMMARY}

From the components for assembly a Fuel filler assembly, the assembly line was selected to improve the productivity. As to meet the Quality improvement pneumatic cylinder were used in 2 shift working condition. 
In addition to the excess investment by adding pneumatic cylinder, the total quality trend and UPH would go up. So we planned to set-up an improvement in that assembly process by eliminating manual assembly method.

Through this, we studied about the process and its behaviours. Upon the studies in the assembly technology semi-automation, we have to make up the possible changes in the fixture clamping design.

There we designed the fixture that is capable of loading 4 components at a time and modification in the clamping system. By this change, we had a possibility of modifying the process parameters for cycle time reduction.

By this modification, we will be able to achieve the tact time by reducing the cycle time up to $50 \%$. This enables us to eliminate the excess manpower and possibility of running in three shifts a day.

Table 1: Comparison of Benefits

\begin{tabular}{|c|c|c|}
\hline PHENOMENON & BEFORE & AFTER \\
\hline Productivity & 50 per hour & 110 per hour \\
\hline Rejection & 8 no's per 100 (approx) & 1 no per 100 (approx) \\
\hline Safety & Possibility to hand injury & Safety enhanced \\
\hline Morale & Operator fatigue & Fatigue elimination \\
\hline Working shift & 3Shift & 2 Shift \\
\hline
\end{tabular}

\section{CONCLUSIONS}

The following conclusion can be drawn based on the experimental study in "Optimization of Semi Automation in Assembly line".

- An elaborated study in the Selection of fixture and its characteristics.

- Designing the fixtures for assembly in an optimized way.

- Analysis in the cycle time.

- Cost analysis and process analysis are done.

- The cycle time and set-up time are reduced by $50 \%$.

\section{REFERENCES}

1. Dennis B.Hobbs,Lean manufacturing implementation, Dennis B.Hobbs, J.Ross publishing,Inc.,2004,76-90.

2. Gary K.Griffith,Statistical process control methods, Jean W.Bohn, ASQC Quality press, 1996,25-30.

3. Joshi P.H, Jigs and Fixtures Design manual, Robert O. Parmley, The McGraw-Hill, 2003, 180-185.

4. V. Balambica, T. Madhan Raj, C. Dinesh,A. Mohamed Azharudeen2 \& K. Harish.," Influence Of Stresses In A Modified Non-Metallic Spur Gear Pair”., Issue 6,Dec 2018, pp 239-248.,International Journal of Mechanical and Production Engineering Research and Development (IJMPERD)., Transtellar Journal Publications., Vol. 8.,ISSN (P): 2249-6890; ISSN (E): 2249-8001.

5. V. Balambica, R. Sachin Ritto, B. Balamuralidharan, T. Rajadurai \& A. Akthar.," Effect Of Negative Correction Factor In Spur Gear Tooth Profile Using Fea”., Issue 2,Dec 2018, pp 1-6., International Journal of Industrial Engineering \& Technology (IJIET).,Transtellar Journal Publications., Vol. 8., ISSN (P): 2277-4769; ISSN (E): 2278-9456. 
6. Dr. V. Balambica., Vishwa Deepak, "Study and Analysis of Reducing Hand Vibration in Tractor”, November 2017.,PP 275279.,International Journal of Pure and Applied Mathematics., Publisher Academic Publications Ltd., Volume 116.,Special.,ISSN Print 1211-8080.,ISSN Online-1394-3395.

7. Shanmuganandam K., Heat transfer enhancement in shell and tube heat exchangers using twisted tapes, International Journal of Mechanical Engineering and Technology,V-8,I-8,PP-1565-1568,Y-2017.

8. Sivakumar K., Mohanamurugan S., Nagarajan P.K., Vijay R., Sabarish R., Multiobjective optimum design of gear box issues and challenges, Journal of the Balkan Tribological Association, V-21,I-3,PP-676-689,Y-2015

9. Lenin A.W.A., Periyasamy N., George L., Influence of interlayer thickness (Zn) on the Properties of Al 7020 FSW Joints, Materials Research,V-19,I-4,PP-817-823,Y-2016

10. Umanath K., Palanikumar K., Selvamani S.T., Analysis of dry sliding wear behaviour of Al6061/SiC/Al2O 3 hybrid metal matrix composites, Composites Part B: Engineering, V-53,I-,PP-159-168, Y-2013

11. Anbazhagan R., Satheesh B., Gopalakrishnan K., Mathematical modeling and simulation of modern cars in the role of stability analysis, Indian Journal of Science and Technology, V-6,I-SUPPL5,PP-4633-4641,Y-2013

12. Srinivasan V., Analysis of static and dynamic load on hydrostatic bearing with variable viscosity and pressure, Indian Journal of Science and Technology, V-6,I-SUPPL.6,PP-4777-4782,Y-2013

13. Prem Jeya Kumar M., Gopalakrishnan K., Srinivasan V., Anbazhagan R., Sundeep Aanan J.,PC modeling and simulation of car suspension system,Indian Journal of Science and Technology, V-6,I-SUPPL5,PP-4629-4632,Y-2013

14. Sivakumar, S., Ranjithkumar, N., \& Ragunathan, S. (2013). Design and development of down draft wood gasifier. International Journal of Mechanical Engineering, 2(2), 1-10.

15. Balambica V., Prabhu T.J., Babu R.V, Finite element application of gear tooth analysis, Advanced Materials Research, V889-890,I-,PP-527-531,Y-2014

16. Ashok K.P., Babu R.V., Balambica V.,A study on diesel engine performance depends on BP and BSFC by applying different injection pressure, International Journal of Mechanical Engineering and Technology, V-9,I-11,PP-599-603,Y-2018

17. Shriram Kumaar Pandian P., Jose Ananth Vino V., Meenakshi C.M., Reduce cycle time through kanban replenishment using streamlining material flow, International Journal of Applied Engineering Research, V-9,I-22,PP-7814-7819, Y-2014

18. Jose Ananth Vino V., Solomon R., Sreenath S., Performance analysis of spark ignition engine fueled with methanol/petrol fuel blends, Indian Journal of Science and Technology, V-6,I-SUPPL5,PP-4579-4582, Y-2013

19. Jose Ananth Vino V., Solomon R., Sreenath S., Performance analysis of spark ignition engine fueled with methanol/petrol fuel blends, Indian Journal of Science and Technology, V-6,I-SUPPL5,PP-4579-4582, Y-2013

20. Meenakshi C.M., Kumar A., Priyadarshi A., Dash D.K., Krishna H.,Analysis of spur gear using finite element analysis, Middle - East Journal of Scientific Research, V-12,I-12,PP-1672-1674,Y-2012

21. Rubanprakash, Rakesh, Aravindan, Jothimurugan, Meenakshi C.M., Design and fabrication of hydro power generation system from waste water, International Journal of Mechanical Engineering and Technology, V-8,I-8,PP-1606-1609,Y-2017

22. Dheeraj S., Sabarish R., Analysis of truck chasis frame using FEM, Middle - East Journal of Scientific Research,V-20,I5,PP-656-661,Y-2014

23. KM, S., GL, S., BK, A. K., \& Anand, A. (2016). Foam Finned Down Flow Type Automotive Radiator Rating and Sizing. 
24. Thirumavalavan S., Sabarish R., Ganesan U., Experimental investigation on friction stir welded aluminium-scilicon alloy, International Journal of Mechanical Engineering and Technology, V-8,I-8,PP-1629-1641,Y-2017

25. Kumar A., Sabarish R.,S tructural and thermal analysis of brake drum, Middle - East Journal of Scientific Research,V-20,I8,PP-1012-1016,Y-2014

26. Nimal R.J.G.R., Hariharan R., Karthikeyan R., Design and fabrication of an indexing fixture in a shaper machine, International Journal of Mechanical Engineering and Technology,V-8,I-8,PP-1594-1600,Y-2017

27. Christopher M., Sabarish R., Emission analysis of a single cylinder di engine running on biodiesel blend as fuel,Middle East Journal of Scientific Research, V-20,I-6,PP-681-684,Y-2014

28. Venkatesan M., Vikram C.J., Naveenchandran P., Performance and emission analysis of pongamia oil methyl ester with diesel blend, Middle - East Journal of Scientific Research, V-12,I-12,PP-1758-1765, Y-2012

29. Tarun Y., Thamotharan C., Naveenchandran P., Performance of methanol blended diesel fuels in twin cylinder diesel engine, Middle - East Journal of Scientific Research, V-17,I-12,PP-1775-1778, Y-2013

30. Balaji V., Ravi S., Naveen Chandran P., Experimental investigation of cryogenic cooling in CO2and performance of tin coated insert in conventional milling of AISI H13 steel, Journal of Advanced Research in Dynamical and Control Systems, V9,I-Special Issue 12,PP-2225-2238,Y-2017

31. Balaji V., Ravi S., Naveen Chandran P.,FEM method structural analysis of pressure hull by using hyper mesh, International Journal of Engineering and Technology(UAE),V-7,I-1.5 Special Issue 5,PP-258-263,Y-2018

32. Chandrabose S., Thamotharan C., Naveenchandran P., Anbazhagan R., Design optimization and analysis of a parabolic leaf spring,Middle - East Journal of Scientific Research, V-20,I-11,PP-1590-1596, Y-2014

33. Fradaric John C., Christu Paul R., Christopher Ezhil Singh S., Sengottuvel P., Corrosion resistance on Al-12Si-xZrC composites using acid mediums, International Journal of Mechanical and Mechatronics Engineering, V-17,I-5,PP-67-74,Y2017

34. Gupta, A., Tewari, P. C., \& Garg, R. K. (2013). Evaluation and Selection of Inventory Policies by MCDM-Matrix Method: A Case Study for Passenger Vehicle for Automotive Industry in India. International Journal of Research in Business Management, 1(2), 1-10.

35. Karunakaran P., Jegadheesan C., Dhanapal P., Sengottuvel P., Sugar industry fly ash: An additive for molding sand to make aluminium castings, Russian Journal of Non-Ferrous Metals, V-55,I-3,PP-247-253, Y-2014

36. Dhanasekar J., Sengottuvel P., Hussain H.J., Design of bio-potential data acquisition system for the physically challenged, Journal of Industrial Pollution Control, V-33,I-2,PP-1542-1546,Y-2017

37. Manikandan J., Hussain J.H., Design on blind shoe using ATMEGA328 micro controller, International Journal of Mechanical Engineering and Technology, V-8,I-8,PP-1575-1579, Y-2017

38. Dhanasekar J., Sengottuvel P., Hussain H.J., Design of bio-potential data acquisition system for the physically challenged, Journal of Industrial Pollution Control, V-33,I-2,PP-1542-1546,Y-2017 
